\title{
МУЗЕЕВЕДЕНИЕ
}

DOI: $10.17805 / g g z .2017 .3 .8$

\section{История, современное состояние и перспективы музеев России}

\author{
Т. М. ГУДИМА \\ МОСКОВСКИЙ ГУМАНИТАРНЫЙ УНИВЕРСИТЕТ
}

В статье рассматривается прошлое, настоящее и будущее российских музеев. Если универсальная модель останется без изменения, музеям предстоит принципиально изменить свою работу.

Ключевые слова: культурология; музееведение; российские музеи

\section{History, Current State and Prospects of Russian Museums}

\author{
T. M. GUDIMA \\ MOSCOW UNIVERSITY FOR THE HUMANITIES
}

The article discusses the past, present and future of Russian museums. If the generic model remains unchanged, museums will need to fundamentally change their work.

Keywords: cultural studies; museum studies; Russian museums

В культурной жизни любого цивилизованного общества огромная роль принадлежит музеям. Этот культурный институт (храм) был создан человечеством для сохранения, актуализации и передачи следующим поколениям наиболее ценной части природного и культурного наследия. Музеи - олицетворение преемственности, связи поколений, единства исторического процесса, это сокровищница опыта и мудрости людей, живших и живущих на земле, история их поисков и ошибок, открытий и заблуждений.

В России начало становления музейного дела связано с историей древлехранилищ при монастырях, с созданием по распоряжению Петра I кунсткамеры, распространением в помещичьих усадьбах и крестьянских домах комнат и уголков памяти о предках, сохранением изображений и подлинных вещей. Осмысление роли музеев в жизни общества, их организационное оформление в России специалисты связывают с концом XIX и началом XX в. Первые музейные проекты разрабатывали члены знаменитого Румянцевского общества, много сделавшего для просвещения народов России. Большой резонанс получила статья философа-утописта, космиста Н. Ф. Федорова «Музей, его смысл и назначение». В соответствии с главной идеей своей философии - патрификацией: возможностью мысленного и реального воскрешения всех предков, Н. Ф. Федоров определял музей как «высшую инстанцию, которая должна и может возвращать жизнь» (Федоров, 1982).

1910-1920-е годы в России были периодом бурного развития всех направлений музейной деятельности. Была разработана типология музеев, проведена их классифика- 
ция. Музеи были очень многообразные: научные для специалистов, учебные для учащихся различных категорий, публичные (исторические, природные, биологические, художественные и другие) для массового посетителя. Со второй половины XIX в. широкое распространение и популярность получили мемориальные музеи, связанные с жизнью великих людей.

В годы Советской власти существенно усилилось внимание государства к деятельности музеев, они стали составной частью единой идеологической системы. Это во многом формировало экспозицию музея, определяло тематику выставок. Среди всех задач, которые должен решать музей в своей сущности: создание, изучение, сохранение и публичное представление коллекций, на первое место выдвигалась одна, главная задача: коммунистическое воспитание советских людей. Музеи финансировались государством, цены билетов были низкими и общедоступными. Авторитет музейных работников поддерживался государством, и, несмотря на маленькую зарплату, работать в музеях было престижно.

Период «перестройки»- коренного изменения социально-экономического строя в стране поставил учреждения культуры, в том числе музеи, в крайне сложное положение: финансирование резко сократилось, и учреждениям культуры настойчиво рекомендовали «вписываться в рынок», учиться зарабатывать деньги. В это трудное время большинство музеев сохранилось и продолжали работать только благодаря преданности своему делу, самоотверженности сотрудников музеев. Последние тридцать лет развития музейного дела были крайне сложным, противоречивым и продуктивным периодом, многое в музеях изменилось. Есть изменения радующие, открывающие перспективы развития, есть тревожные, угрожающие будущему музеев. Все это требует осмысления и серьезного анализа.

Международный Союз Музеев - ИКОМ, членом которого является Россия, определяет современный музей как «постоянное некоммерческое учреждение, которое призвано служить обществу и способствовать его развитию, доступно широкой публике и осуществляет популяризациюю и әкспонирование материальных свидетельств о человеке и его среде обитания в целях изучения, образования, а также для удовлетворения духовных потребностей общества».

Проанализируем современное состояние и динамику развития музеев в нашей стране. В анализе будем опираться на данные официальных документов: Концепцию «Основы государственной культурной политики», подписанную Президентом 24 декабря 2014 г., «Стратегию государственной культурной политики», утвержденную распоряжением Главы Правительства 29 февраля 2016 г. и проектом Концепции развития музейного дела в Российской Федерации на период до 2030 года, разработанным Министерством культуры РФ в конце 2016 г. и представленным для обсуждения в 2017 г. (Основы..., Стратегия..., Проект... Электронный ресурс).

В России в 2016 г. работают 2758 музеев всех ведомств, в том числе 653 филиала. За последние пять лет число музеев увеличилось на 237, из них 43 филиала. Музейный фонд составляет 88,2 млн единиц хранения. Из общего количества музеев 63 с 31 филиалом являются федеральными, то есть финансируются федеральным бюджетом; 827 музеев учреждены органами власти субъектов федерации и их благополучие целиком зависит от экономического и финансового состояния области или республики. Самое большое число музеев - 1709, или $65 \%$ от всех существующих, являются муниципальными, т. е. должны финансироваться местными органами власти, в бюджетах которых нет средств даже на самое необходимое. 
В самом трудном положении находятся сейчас именно муниципальные музеи, а именно они чаще всего являются культурными центрами села, поселка, малого города. По содержанию работы эти музеи чаще всего - краеведческие, в них собраны уникальные материалы по истории родного края, работают объединения историков и краеведов. Только здесь вы можете узнать о людях, родившихся, выросших на этой земле и свершивших добрые дела во имя Отечества. Эти музеи проводят многочисленные мероприятия: конференции, круглые столы, исторические и литературные праздники. Школьники здесь бывают не от случая к случаю, а постоянно, здесь проходят уроки, дополняющие и обогащающие учебные программы. Подтверждением этого является опыт работы музея города Вельска, поселка Октябрьский Устьянского района Архангельской области, музейное объединение села Вологодской области и многих других.

Решением многих острых проблем муниципальных музеев Министерство культуры считает оптимизацию, что на практике означает объединение в малом городе, селе или поселке музея с библиотекой, домом культуры или клубом, другими организациями культуры в одно учреждение с целью экономии средств и без того мизерных. Нам это решение представляется ошибочным, оно нанесет ущерб, прежде всего содержанию работы и музеев, и библиотек, затормозит, а то и остановит реальное совершенствование, обновление музейной и библиотечной деятельности, которое возможно только на основе профессионализации.

Общая картина музейного дела в стране будет не полной, если не назвать еще ряд ее составляющих. K сожалению, эти музеи не пользуются в стране заслуживающим того вниманием. Это сто музеев Российской Академии наук, только четыре из них имеют юридический статус, остальные являются подразделениями институтов РАН. В России 226 действующих частных музеев, появившихся в последнее десятилетие В советское время (данные 1990 г.) было 4374 общественных музея на предприятиях, в колхозах и совхозах, в воинских частях, школах и институтах. Сейчас их судьба никого, в том числе, Министерство культуры, не интересует. Мы знаем, что ряд из них сохранились и прекрасно работают, но большинству новых собственников и хозяев предприятий музей, как и библиотека, оказался не нужен и прекратил свое существование.

Особое место в музейном мире принадлежит музеям-заповедникам и музеям усадьбам. Их в России 160, и расположены они в 56 субъектах РФ: это музей-заповедник А. С. Пушкина «Михайловское», музей-заповедник М. Ю. Аермонтова «Тарханы», музей-заповедник $\Lambda$. Н. Толстого «Ясная поляна», музеи-заповедники, поля сражений «Бородино» и «Куликово поле», музей-заповедник М. А. Шолохова «Станица Вешенская» и многие другие.

Особенность музеев-заповедников и музеев-усадеб состоит в том, что они являются целостными территориальными комплексами культурного и природного наследия, представляющими материальные и духовные ценности в их исторической среде. В их состав входят культурные и природные ландшафты, городские и сельские поселения. Сотрудники музеев стремятся возродить в музеях-заповедниках свойственный им уклад жизни, традиции и обычаи хозяев и гостей усадьбы. Это очень важная и значимая работа, потому что провинциальная русская усадьба сохраняет образ России XIX-XX века, хорошо описанный в классической русской литературе. Это был образ жизни, позволивший вырастить несколько поколений талантливых, незаурядных личностей: ученых, художников, писателей, врачей, военноначальников и общественных 
деятелей, внесших огромный вклад в историю Отечества. В усадьбах были музеи и библиотеки, домашние театры, оркестры и хоровые коллективы. Важной частью усадьбы были хозяйственные комплексы с передовыми технологиями того времени. Все это музеи-заповедники стремятся восстанавливать, возрождая сам дух русской усадьбы. Это чрезвычайно трудная работа, но она способствует повышению авторитета музеев и практическому решению социально-экономических проблем регионов. Особенно это ощутимо, когда музеи расположены в провинции: они вносят существенный вклад в местные бюджеты, создают возможности трудоустройства, решают другие вопросы жизни людей. Не для красного словца, а истины ради жителей Пушкиногорского района Псковской области называют Александра Сергеевича Пушкина своим кормильцем.

Музеев-заповедников в нашей стране может и должно быть больше. Много лет небольшой коллектив профессионалов-энтузиастов во главе с Верой Валерьевной Стерлиной занимается изучением заброшенных русских усадеб. Они выпустили семь книг с подробным описанием тысяч таких объектов в центральных регионах России. Все они расположены в красивейших местах, имеют интересную и трудную историю, могут быть восстановлены и послужить на благо людей. К сожалению, в ближайшие годы вряд ли этим займется государство, Вся надежда на неравнодушных людей, на тех, кто озабочен судьбами культуры.

Проблем, нерешенных вопросов в музейном деле много, и все-таки идет развитие, работа музеев совершенствуется, становится более современной, отвечающей вызовам времени.

Постараемся определить основные тенденции развития музеев, опираясь на накопленный опыт.

Во-первых, музеи активно внедряют информационные и коммуникационные технологии. 80\% музеев имеют выход в Интернет, 48\% - собственный сайт. Широкое распространение получили электронные экспозиции и виртуальные музеи. Создана реальная возможность многократного увеличения «посещаемости»музеев - одного из главных показателей в оценке деятельности музея. Сейчас, по данным ВЦИОМ, музеи посещают $38 \%$ россиян (2\% - не реже раза в месяц, $21 \%$ - раз в год, $15 \%$ - раз в несколько лет). При этом $51 \%$ хотели бы ходить в музей чаще. Информатизация музеев будет развиваться, это прогрессивное и востребованное направление деятельности, но после посещения самых «модерновых»музеев невольно возникает чувство тревоги, как сохранить, не утратить особое, сокровенное отношение к подлинному, предмету или документу, сохранившему память, душу ушедших эпох. Аля музеев это всегда было очень важно.

Вторым важным направлением совершенствования работы музеев является развитие выставочной и экспозиционной деятельности не только в стенах музея, но и далеко за его пределами. Так, в 2015 г. только в музеях, курируемых Министерством культуры, работало 67133 выставки, на 36,6\% больше, чем в 2011 г. С каждым годом число выставок возрастает, расширяется их география. Это позволило значительно увеличить процент активно используемых фондов. Количество выставок стало одним из основных показателей в оценке деятельности музеев. Вместе с тем, в ряде музеев так увлеклись выставками, что существенно ослабили внимание к содержанию и качеству основной экспозиции. Во многих краеведческих музеях она просто исчезла, ее заменили выставки по отдельным периодам истории страны. Большинство краеведческих музеев (такие музей составляют 40\% общего количества музеев) являются муници- 
пальными, в составе их сотрудников нет научных работников, без участия которых создание постоянной, научно-обоснованной экспозиции невозможно. Таким музеям крайне необходима помощь ученых, научных сотрудников федеральных музеев, Всероссийского исторического общества. Проблема эта государственная и решать ее надо на государственном уровне. По нашему мнению, решение этой задачи есть создание фундамента патриотического воспитания.

В музеях значительное развитие получила просветительская и образовательная функция. Этой работой музеи занимались всегда, но сейчас она приобретает более системный характер: тематика лекториев согласуется с учебными программами школ и других учебных заведений, работают творческие кружки и мастерские, обучающие началам творчества, развивающие таланты, в работу музея активно включаются писатели, музыканты, художники. Накопленный опыт работы дает право говорить об особом воспитательном мастерстве - музейной педагогике. Аля иллюстрации приведу только один пример - программа «Ночи музеев», прошедшей в Архангельске, в музее «Художественная культура Русского Севера» 20-21 мая 2017 г.

Открытие выставки «Север. Художник. Время», «Аети говорят об искусстве - мини-экскурсии юных экскурсоводов», Мастерская «Оранжерея - рисуем в стиле попарт», «Северная песня Виктора Попкова» - презентация работ к юбилею художника, проект «Музейный эксперт: первый показ иконы «Откровение апостола Иоанна Богослова», выставка «Поморские ходичи», персональная выставка «Серебряная линия, ювелирное искусство - встреча с художником, презентация книги «Аитературные имена Севера», фильм «Советский поп-арт»- виртуальный филиал Русского музея, мастер-класс «Узоры на синей воде» - набивка на ткани, выступление ансамбля народной песни музыкального колледжа, проект «Звукоцвет: музыкальные импровизации», презентация нового выставочного зала «Студенческие годы Александра Борисова», выставка «Все на вокзал», посвященная 120-летию открытия Северной железной дороги, интересные лекции, дискуссии, творческие встречи. Участвовали более 2 тыс. человек, они нашли для себя интересное занятие. Названа только пятая часть состоявшихся мероприятий, но и по ним можно представить, какой интересной была программа.

Новым направлением в работе музеев, получившим широкое распространение в последние годы является внедрение интерактивных форм работы, игровых технологий вековое правило, гласившее, что в музее ничего нельзя трогать руками, уходит в прошлое. Это интересное направление, безусловно привлекающее новых посетителей, особенно активно на него откликаются дети. Но внедрение его должно осуществляться с необходимой деликатностью, с высокой степенью уважения к музейному предмету, к музейным коллекциям. Развлекательная функция в музеях не должна потеснить основные функции, во имя которых возник и развивается музей.

Развитие социокультурных функций музеев способствует усилению их влияния на развитие территорий, на решение социальных и даже экономических проблем. К сожалению, управляющие органы призывают все последние годы музейных работников к тому, что музеи должны больше зарабатывать. У музеев другая задача, более важная и более сложная. Кроме музеев никто ее выполнить не может. Вот, например, в мире и в России растет интерес к культурному туризму в самых разных формах. Но остается главный вопрос: что покажет, чем обогатит музей? И на этот вопрос смогут ответить только музеи, только люди, посвятившие свою жизнь сохранению, изучению и популяризации нашего богатейшего культурного наследия. 
В проекте концепции «Развитие музейного дела», которая обсуждается в заинтересованных организациях, к сожалению, не очень активно, предлагается универсальная прогнозируемая модель развития музея. Она представляет триединство, включающее в себя:

- полномасштабное выполнение конституционных функций;

- расширение и развитие социальных функций (усиление социальных связей и сплоченности общества, воспитание граждан, социальную интеграцию уязвимых слоев населения);

- формирование музеями жизненно-важного публичного пространства, которое призвано способствовать развитию территории, благоустройству, ревитализации городской и сельской среды, воспитанию активной гражданской позиции по отношению к наследию.

В недалеком будущем проект концепции будет утвержден и превратится в постановления, распоряжения, приказы, стандарты и другие документы, которые предстоит исполнять. Если предложенная универсальная модель останется без изменения, музеям предстоит принципиально изменить свою работу. Аолжно измениться и место музеев в жизни общества, их роль должна возрасти. Но остается вопрос, готово ли к этому музейное сообщество и готово ли к этому государство, органы которого остаются основными учредителями музеев.

\section{СПИСОК АИТЕРАТУРЫ}

Основы государственной культурной политики. Утверждены указом президента РФ от 24 декабря 2014 г. № 808 [Электронный ресурс]. URL: http://base.garant.ru/70828330/\#ixzz4 mijpgjvT (дата обращения: 01.04.2017).

Проект Концепции развития музейного дела в РФ на период до 2030 года [Электронный ресурс]. URL: http://www.oprf.ru/about/structure/structurenews/newsitem/36888 (дата обращения: 01.04.2017).

Стратегия государственной культурной политики на период до 2030 года. Утверждена распоряжением Правительства Российской Федерации от 29 февраля 2016 г. № 326-р [Электронный ресурс]. URL: http://bvdshi.muzkult.ru/img/upload/2699/documents/strategiya-kulturnojpolitiki.pdf (дата обращения: 01.04.2017).

Федоров, Н. Ф. (1982) Музей, его смысл и назначение // Федоров, Н. Ф. Соч. / под ред. А. В. Гулыги. М. : Мысль. 711 с. С. 575-604.

\section{REFERENCES}

Osnovy gosudarstvennoj kul'turnoj politiki. Utverzhdeny ukazom prezidenta RF ot 24 dekabrya 2014 g. N 808 [online] Avaible at: http://base.garant.ru/70828330/\#ixzz4mijpgjvT (access date: 01.04.2017). (In Russ.)

Proekt Koncepcii razvitiya muzejnogo dela $v$ RF na period do 2030 goda [online] Avaible at: http://www.oprf.ru/about/structure/structurenews/newsitem/36888 (access date: 01.04.2017). (In Russ.)

Strategiya gosudarstvennoj kul'turnoj politiki na period do 2030 goda. Utverzhdena rasporyazheniem Pravitel'stva Rossijskoj Federacii ot 29 fevralya 2016 g. N 326-r [online] Avaible at: http://bvdshi.muzkult.ru/img/upload/2699/documents/strategiya-kulturnoj-politiki.pdf (access date: 01.04.2017). (In Russ.)

Fedorov, N. F. (1982) Muzej, ego smysl i naznachenie. Fedorov, N. F. Sochinenija / pod red. A. V. Gulygi. Moskva, Mysl'. 711 s. S. 575-604. (In Russ.) 
Гудима Тамара Михайловна - кандидат философских наук, доцент, профессор кафедры философии, культурологии и политологии Московского гуманитарного университета. Адрес: 111395, Россия, г. Москва, ул. Юности, 5. Тел.: +7 (499) 374-61-81. Эл. aдрес: gudima.tamara@yandex.ru

Gudima Tamara Mikhailovna, Candidate of Philosophy, Professor, Department of Philosophy, Culturology and Politology, Moscow University for the Humanities. Postal address: 5 Yunosti St., 111395 Moscow, Russian Federation. Tel.: +7 (499) 374-61-81. E-mail: gudima.tamara@yandex.ru

\section{Аля иитирования:}

Гудима Т. М. История, современное состояние и перспективы музеев России [Электронный ресурс]// Горизонты гуманитарного знания. 2017, № 3. URL: http://journals.mosgu.ru/ggz/article/view/518 (дата обращения: Ад.мм.гггг.). DOI: 10.17805/ggz.2017.3.8 